Dig Surg 1994;11:47-48

\title{
Contents, Vol. 11, No. 2, 1994
}

Kirchner, R.; Maruyama, K.

Preface

49

Macintyre, I.M.C.

Improving Survival in Gastric Cancer: A Review

51

Gouzi, J.L.; Bloom, E.; Labbé, F.; French Associations for Surgical Research

Total versus Subtotal Gastrectomy for Adenocarcinoma of the Gastric Antrum 58

Ohgami, M.; Kumai, K.; Otani, Y.; Wakabayashi, G.; Kubota, T.; Kitajima, M.

Laparoscopic Wedge Resection of the Stomach for Early Gastric Cancer Using a Lesion-Lifting Method

64

Huguier, M.; Houry, S.; Landen, S.

Prognostic Significance of Lymph Node Involvement in Gastric Carcinoma Resected with Curative Intent

68

Meyer, H.-J.; Jaehne, J.

Rationale and Technique of Systematic Lymph Node Dissection in Gastric Carcinoma 72

Isozaki, H.; Okajima, K.

How to Reduce Surgical Complications after Extended Gastric Surgery

78

Songun, I.; Bonenkamp, J.J.; Sasako, M. Bunt, A.M.G.; Hermans, J.; van de Velde, C.J.H.; Dutch Gastric Cancer Group

Kaibara, N.; Maeta, M.

Katai, H.; Maruyama, K.; Sasako, M.; Sano, T.; Okajima, K.; Kinoshita, T.; Naparkov, A. Current Results of Randomized Studies about the Extent of Lymph Node Dissection. Quality Control in Lymphadenectomy for Gastric Cancer in a Prospective Randomized Multicenter Trial in the Netherlands

Limits of Lymph Node Dissection in Advanced Gastric Cancer

Mode of Recurrence after Gastric Cancer Surgery

9399

Kirchner, R. Surgical Strategies for the Treatment of Gastric Cancer Considering Intraoperative Radiation Therapy

Lise, M.; Nitti, D.; Marchet, A.; $\quad$ Adjuvant Chemotherapy for Gastric Cancer. Results of Recent 111

Fornasiero, A.; Sahmoud, T.; Duez, N. $\quad$ European Clinical Trials 
Finke, J.; Engelhardt, R.

Chemotherapy for Advanced Gastric Cancer

118

Haugstvedt, T.

Benefit of Resection in Palliative Surgery

121

Author Index

126

Subject Index 126

48

Contents 